\title{
Vitamin C and exercise-induced bronchoconstriction in athletes
}

: [Letter]

\section{Hemilä, Harri}

2009

Hemilä , H 2009 , ' Vitamin C and exercise-induced bronchoconstriction in athletes : [Letter] '

, Journal of Allergy and Clinical Immunology , vol. 123 , no. 1 , pp. 274-275 . https://doi.org/10.1016/j.jaci.2008.10.00

http://hdl.handle.net/10138/228475

https://doi.org/10.1016/j.jaci.2008.10.004

publishedVersion

Downloaded from Helda, University of Helsinki institutional repository.

This is an electronic reprint of the original article.

This reprint may differ from the original in pagination and typographic detail.

Please cite the original version. 
The section on urticaria and angioedema mentions case reports on the use of omalizumab in idiopathic angioedema. ${ }^{2}$ We published 3 earlier case reports on the efficacy of omalizumab in intractable chronic urticaria. ${ }^{3}$ We reported on 3 patients with refractory chronic urticaria who had marked improvement with omalizumab. Two of the patients showed evidence of increased anti-FceRI antibody levels, and 1 did not. We postulated that the possible mechanisms included the downregulation of $\mathrm{IgE}$ receptors, providing fewer targets for $\operatorname{IgE}$ or anti-FceRI antibodies.

All our patients were started on injections every 2 weeks (based on weight and IgE level) but are currently still doing well with increasing the intervals between injections to every 4 weeks. We have also started 2 additional patients on omalizumab, with similar significant clearing of urticaria within 1 week.

Successful treatment of urticaria with anti-IgE therapy has also been reported by other authors. ${ }^{4,5}$ Omalizumab appears to be a very promising therapeutic alternative for refractory urticaria and angioedema.

Sheldon L. Spector, MD Ricardo A. Tan, MD

From the California Allergy and Asthma Medical Group, Los Angeles, Calif. E-mail: rtantan@aol.com.

Disclosure of potential conflict of interest: S. L. Spector has received honoraria, consulting fees, or both from Abbott, Amgen, AstraZeneca, Genentech, Novartis, Sanofi-Aventis, and Schering-Plough and has received research support from Amgen, AstraZeneca, Boehringer Ingelheim, Genentech, GlaxoSmithKline, Novartis, SanofiAventis, Schering-Plough, and Skypharma. R. A. Tan has declared that he has no conflict of interest.

Editor's note: There is no accompanying reply to this correspondence.

\section{REFERENCES}

1. Sicherer SH, Leung DYM. Advances in allergic skin disease, anaphylaxis, and hypersensitivity reactions to foods, drugs, and insects in 2007. J Allergy Clin Immunology 2008;121:1351-8.

2. Sands MF, Blume JW, Schwartz SA. Successful treatment of 3 patients with recurrent idiopathic angioedema with omalizumab. J Allergy Clin Immunol 2007;120: 979-81.

3. Spector SL, Tan RA. Effect of omalizumab in patients with chronic urticaria. Ann Allergy Asthma Immunol 2007;99:190-3.

4. Boyce JA. Successful treatment of cold-induced urticaria/anaphylaxis with anti-IgE. J Allergy Clin Immunol 2006;117:1415-8.

5. Metz M, Bergmann P, Zuberbier T, Maurer M. Successful treatment of cholinergic urticaria with anti-immunoglobulin E therapy. Allergy 2008;63:247-9.

Available online September 9, 2008 doi:10.1016/j.jaci.2008.07.033

\section{Vitamin C and exercise-induced bronchocon- striction in athletes}

\section{To the Editor:}

Anderson and Kippelen ${ }^{1}$ reviewed the mechanisms of and therapeutic approaches to exercise-induced bronchoconstriction (EIB) in athletes. In addition to the treatments they discussed, vitamin $\mathrm{C}$ can also affect EIB.

We carried out a systematic review of the effect of vitamin $\mathrm{C}$ supplementation on the common cold. ${ }^{2,3}$ Vitamin C consistently reduced the duration of common cold symptoms, but the effect on common cold incidence was significantly heterogeneous. In the general population, vitamin $\mathrm{C}$ supplementation had no preventive effect; however, the supplements halved the incidence of colds in 6 placebo-controlled trials with participants under heavy acute physical stress: pooled relative risk, 0.50 (95\% CI, 0.38-0.66; total, $n=642$ ). Four of these trials were with marathon runners,
1 was with Canadian soldiers in a northern training exercise, and 1 was with schoolchildren in a skiing camp in the Swiss Alps. ${ }^{2,3}$

In the general community the acute symptoms of cough, sore throat, and runny nose usually have a viral cause. However, it is not obvious that similar symptoms occurring after a marathon run are caused by a viral infection because they can result from an injury to runners' airways caused by their hours of exceptional ventilatory exertion. ${ }^{1}$ Thus the common cold studies of marathon runners might have been measuring, at least in part, the effects of vitamin $\mathrm{C}$ on the physical injury to their airways instead of viral infections.

In their trial with marathon runners, Peters et $\mathrm{al}^{4}$ recorded the "self-reported symptoms including a running nose, sneezing, sore throat, cough, and fever" during a 2-week postrace period. The incidence of postrace cough was significantly reduced in the vitamin $\mathrm{C}$ group compared with the placebo group: relative risk, 0.29 (95\% CI, $0.10-0.83$; $4 / 43$ vs 13/41). The incidence of sore throat was also reduced by vitamin $\mathrm{C}$ : relative risk, 0.33 (95\% CI, 0.16-0.66; 8/43 vs 23/41). In contrast, vitamin $C$ had no significant effect on the incidence of runny nose $(P=.2)$. Peters did not carry out virologic or pulmonary function tests before or after the race, and thus the cause of the symptoms is uncertain, yet there is no strong basis to assume viruses caused the symptoms. Furthermore, a few studies have directly measured the effect of vitamin $\mathrm{C}$ supplementation on bronchial responsiveness.

Ogilvy et $\mathrm{al}^{5}$ reported that vitamin $\mathrm{C}$ reduced the duration and intensity of bronchoconstriction induced by methacholine. The action of vitamin $\mathrm{C}$ was abolished by indomethacin, indicating that the effect was mediated through the prostaglandin metabolism. Direct evidence indicating that vitamin $\mathrm{C}$ affects EIB was found in 3 small $(n \leq 20)$ laboratory studies in which the decrease of $\mathrm{FEV}_{1}$ after exercise was attenuated by vitamin $\mathrm{C}$ supplementation. ${ }^{6-8}$ Tecklenburg et $\mathrm{al}^{8}$ also reported that vitamin $\mathrm{C}$ decreased the levels of proinflammatory eicosanoids in urine. These 3 laboratory studies do not, however, define the clinical importance of vitamin $\mathrm{C}$ for athletes. On the other hand, the 6 trials with participants under heavy acute physical stress $^{2,3}$ indicate that vitamin $C$ has clinically important effects on the respiratory symptoms of some athletes, although it is not clear to what degree that effect is directed at their viral infections and the physical injury to their airways. This means that more trials that examine the mechanisms and therapeutic effects of vitamin $\mathrm{C}$ on the respiratory symptoms of athletes are warranted.

Harri Hemilä, MD, PhD

From the Department of Public Health, University of Helsinki, Helsinki, Finland. E-mail: harri.hemila@helsinki.fi.

Disclosure of potential conflict of interest: The author has declared that he has no conflict of interest.

Editor's note: There is no accompanying reply to this correspondence.

\section{REFERENCES}

1. Anderson SD, Kippelen P. Airway injury as a mechanism for exercise-induced bronchoconstriction in elite athletes. J Allergy Clin Immunol 2008;122:225-35.

2. Douglas RM, Hemilä H, Chalker EB, Treacy B. Vitamin C for preventing and treating the common cold. Cochrane Database Syst Rev 2007;3:CD000980.

3. Hemilä H. Do vitamins $\mathrm{C}$ and $\mathrm{E}$ affect respiratory infections? [thesis]. Helsinki, Finland: University of Helsinki; 2006. p. 46-51. Available at: http://ethesis.helsinki. fi/julkaisut/laa/kansa/vk/hemila. Accessed October 24, 2008.

4. Peters EM, Goetzsche JM, Grobbelaar B, Noakes TD. Vitamin C supplementation reduces the incidence of postrace symptoms of upper-respiratory-tract infection in ultramarathon runners. Am J Clin Nutr 1993;57:170-4. 
5. Ogilvy CS, DuBois AB, Douglas JS. Effects of ascorbic acid and indomethacin on the airways of healthy male subjects with and without bronchoconstriction. J Allergy Clin Immunol 1981;67:363-9.

6. Schachter EN, Schlesinger A. The attenuation of exercise-induced bronchospasm by ascorbic acid. Ann Allergy 1982;49:146-51.

7. Cohen HA, Neuman I, Nahum H. Blocking effect of vitamin C in exercise-induced asthma. Arch Pediatr Adolesc Med 1997;151:367-70.

8. Tecklenburg SL, Mickleborough TD, Fly AD, Bai Y, Stager JM. Ascorbic acid supplementation attenuates exercise-induced bronchoconstriction in patients with asthma. Respir Med 2007;101:1770-8.

Available online November 7, 2008 doi:10.1016/j.jaci.2008.10.004

\section{Levalbuterol kinetics}

\section{To the Editor:}

We read with interest the results of Tripp et al, ${ }^{1}$ who used a cumulative dose-response protocol to compare hydrofluoroalkane (HFA) formulations of either levalbuterol or racemic albuterol in asthmatic subjects. They found that plasma levels of R-albuterol were lower after levalbuterol (ie, R-enantiomer) than after racemic (ie, RS) albuterol in conjunction with reduced heart rate but not potassium response when levalbuterol was administered at a $1: 2 \mu \mathrm{g}$ dose ratio.

These results are contrary to previous observations with nebulized administration, in which plasma levels of R-albuterol were higher after levalbuterol than after racemic albuterol in either healthy volunteers or asthmatic subjects, with no difference in extrapulmonary $\beta_{2}$-mediated responses, such as heart rate and potassium level. ${ }^{2,3}$ It is known that the $S$-enantiomer of albuterol is inactive on extrapulmonary $\beta_{2}$-adrenoceptors, whereas plasma levels of S-albuterol are higher after administration of the S-enantiomer than after the equivalent dose of the racemate, as is the case with the R-enantiomer. ${ }^{2}$ It would be hard to explain why heart rate but not potassium response was attenuated with levalbuterol in the study of Tripp et $\mathrm{al}^{1}$ when both are mediated by the same systemic $\beta_{2}$-adrenoceptor and are dependent on peak albuterol plasma levels. ${ }^{4}$ Perhaps one explanation for the results of Tripp et $\mathrm{al}^{1}$ might be that the particular kinetics of HFA levalbuterol are different from those of HFA racemic albuterol in terms of delivering a relatively lower fine-particle dose, resulting in lower plasma R-albuterol levels. This hypothesis could easily be verified by providing supporting data with these formulations on the overall in vitro fine-particle dose $(<4.7 \mu \mathrm{g})$ with an Anderson Cascade Impactor over stages 3 to 7 because the in vitro fineparticle dose determines the in vivo early lung bioavailability and associated peak systemic $\beta_{2}$ adverse effects.

Brian J. Lipworth, $M D$ Karine Clearie, $M B B S$

From the Asthma and Allergy Research Group, University of Dundee, Dundee, United Kingdom. E-mail: brianlipworth@googlemail.com.

Disclosure of potential conflict of interest: B. J. Lipworth has received consulting fees from Neolab, Vectura, and Mundipharma; has served on the advisory board and speakers' bureau for TEVA; has served on the speakers' bureaus for Merck, AstraZeneca, and Schering-Plough; has provided postgraduate educational support meetings for GlaxoSmithKline; has received research support from AstraZeneca, TEVA, Neolab, Pharmaxis, Altana, Merck, and Verus; and has served as an expert witness for Hexal (salbutamol HFA), TEVA (formoterol DPI), and AstraZeneca (budesonide HFA). K. Clearie has received research support as a principal investigator from AstraZeneca.

Editor's note: There is no accompanying reply to this correspondence.

\section{REFERENCES}

1. Tripp K, McVicar WK, Nair P, Corren J, Pleskow WW, Goodwin E, et al. A cumulative dose study of levalbuterol and racemic albuterol administered by hydrofluoroalkane-134a metered-dose inhaler in asthmatic subjects. J Allergy Clin Immunol 2008; 122:544-9.

2. Lipworth BJ, Clark DJ, Koch P, Arbeeny C. Pharmacokinetics and extrapulmonary beta 2 adrenoceptor activity of nebulised racemic salbutamol and its $\mathrm{R}$ and $\mathrm{S}$ isomers in healthy volunteers. Thorax 1997;52:849-52.

3. Gawchik SM, Saccar CL, Noonan M, Reasner DS, DeGraw SS. The safety an efficacy of nebulized levalbuterol compared with racemic albuterol and placebo in the treatment of asthma in pediatric patients. J Allergy Clin Immunol 1999;103: $615-21$

4. Fowler SJ, Lipworth BJ. Pharmacokinetics and systemic beta2-adrenoceptor-mediated responses to inhaled salbutamol. Br J Clin Pharmacol 2001;51:359-62.

5. Lipworth BJ, Clark DJ. Lung delivery of salbutamol by dry powder inhaler (Turbuhaler) and small volume antistatic metal spacer (Airomir CFC-free MDI plus NebuChamber). Eur Respir J 1997;10:1820-3.

doi:10.1016/j.jaci.2008.10.055 